Relations industrielles

Industrial Relations

\title{
Urban Complex of an Industrial City, by Jugendra Sahai, Allahbad, India, Chugh Publishing Company, 1980.
}

\section{Hem C. Jain}

Volume 38, numéro 1, 1983

URI : https://id.erudit.org/iderudit/029346ar

DOI : https://doi.org/10.7202/029346ar

Aller au sommaire du numéro

Éditeur(s)

Département des relations industrielles de l'Université Laval

ISSN

0034-379X (imprimé)

1703-8138 (numérique)

Découvrir la revue

Citer ce compte rendu

Jain, H. C. (1983). Compte rendu de [Urban Complex of an Industrial City, by Jugendra Sahai, Allahbad, India, Chugh Publishing Company, 1980.] Relations industrielles / Industrial Relations, 38(1), 194-195.

https://doi.org/10.7202/029346ar

Tous droits réservés @ C Département des relations industrielles de l'Universite Laval, 1983
Ce document est protégé par la loi sur le droit d'auteur. L’utilisation des services d'Érudit (y compris la reproduction) est assujettie à sa politique d'utilisation que vous pouvez consulter en ligne.

https://apropos.erudit.org/fr/usagers/politique-dutilisation/ 
Ce livre est divisé en sept parties: notice historique sur le syndicalisme espagnol; les syndicats dans la Constitution; les syndicats et les partis politiques; attitudes sociales face aux syndicats; la répartition et les données du pouvoir syndical; l'exercice du pouvoir syndical et ses mécanismes; le syndicalisme et les communautés autonomes.

Dans le troisième chapitre, ils classifient d'abord les rapports entre syndicats et partis politiques en trois variantes: a) syndicat et parti en tant qu'expressions respectives du mouvement ouvrier, basées sur la même assise sociale. Cette variante est présente en plusieurs formules différentes: social démocrate, travailliste, léniniste et autarchique; b) la communauté de principes et de conviction entre le syndicat et le parti (par ex. le syndicalisme chrétien en Belgique); c) le syndicat non alinié sur le parti. Les auteurs examinent ensuite en détail la situation du pays, en se servant d'une très intéressante enquête sur les rapports entre syndicats et partis politiques en Espagne, réalisée par J.A. Sagardoy pour le compte de la Fondation allemande Konrad Adenauer - et dont il ressort, notamment, que le parti et le syndicat les plus clairs et les moins ambigus quant à leurs affinités réciproques sont le PSOE et l'UGT.

Il en ressort également que si, dans la société actuelle, l'union partis-syndicats n'est pas généralement admise, l'«apoliticité» du syndicat ne l'est pas non plus - ce qui est important. Le rôle que joue le syndicat en tant qu'agent de changement - et, donc, comme acteur politique $-\mathrm{y}$ est souligné.

Les auteurs examinent les diverses déclaration des leaders du mouvement ouvrier et syndical espagnol quant à leurs rapports réciproques. Il résulte de ce très intéressant volume sur le fonctionnement, le financement, la structuration et l'influence du syndicalisme espagnol, que les syndicats détiennent un pouvoir authentique, le pouvoir syndical, et qu'ils forment une composante essentielle, désormais, des préoccupations quotidiennes des citoyens.

\section{P. JOUBERT}

Institut d'Administration

des Entreprises, Paris

Urban Complex of an Industrial City, by Jugendra Sahai, Allahbad, India, Chugh Publishing Company, 1980.

This is an interesting study of a developing industrial urban complex (steel mill town) in India. The aim of this study is to analyze the relationship between urban growth and social and economic development. This study is embedded in the theoretical framework developed by two western sociologists, i.e. Hoselitz and Lerner.

Hoselitz has argued that urbanization, economic growth and cultural change are interrelated Lerner's main thesis is that an increase in urbanization is associated with the increase in literacy and the use of mass communication media, regardless of population density. The advocates of 'similar path theory' contend that theoretical models utilized to explain social and economic changes in the west can be superimposed upon the developing countries.

Dr. Sahai's empirical investigation indicates that the Western 'Similar path' models are inadequate in explaining the relationship between urban growth and economic development in India. One of his most important research findings is that even an industrial urban complex like Durgapur steel city has not been able to exercise a "generative impact' on the region in which it is located. The author has examined various aspects of formal and informal participation of labour force in this steel city to test available theoretical concepts. His study reveals that urban growth is positively correlated with the disorganization aspect of the city. "Both personal and social disorganization are looming large in the city resulting into the impairment of harmonious social relations. ....various 
kinds of crimes show a rising trend... The city's growth has miserably failed to accelerate changes in the surrounding region of which it is a part. Urban growth in the region has failed to generate economic growth and cultural change."

Dr. Sahai's empirical study is a pioneering work in the field of urban sociology in the sense that it has brought a fresh perspective on the relationship between urbanization and regional development in a developing country. However, the author does not give the reasons why Duragapur Steel city has failed to rise to the status of 'generative city' and has remained a 'parasitic city'. This could be another fruitful area of research.

\section{Hem C. JAIN}

University of New Brunswick

Le changement planifié, par Pierre Collerette et Gilles Delisle, Montréal, L'Agence d'Arc Ltée Inc., 1982, 213 pp., ISBN 0-89022-045-1

$\mathrm{Au}$ moment où l'on s'intéresse activement à l'amélioration de la qualité de la vie au travail par la mise en oeuvre de changements majeurs au plan de la structure et du climat des organisations de travail, ou encore au plan de la technologie, la publication de cet ouvrage arrive à point. Au lieu de traiter du contenu des changements, c'est-à-dire telle ou telle modification apportée à un système organisationnel, les auteurs, consultants et professeurs, ont cherché plutôt à décrire le processus même du changement, et, plus précisément, du changement planifié qu'ils définissent comme «un effort délibéré de changer une situation dite insatisfaisante, au moyen d'une suite d'actions dont le choix et l'orchestration résultent d'une analyse systématique de la situation en cause» (p. 49).

Après avoir présenté un cadre conceptuel emprunté à la théorie des systèmes, les auteurs traitent de la notion du changement en général, de ses sources et de ses mécanismes, pour présenter par la suite la démarche pro- pre au changement planifié qui se décompose dans ses phases principales, diagnostic de la situation existante, de la planification des actions, d'exécution et d'évaluation. Au cours du processus complet ou au cours de l'une de ses phases, une foule de considérations entrent en ligne de compte qui font l'objet de chapitres particuliers: processus de formation et de changement d'attitudes; forces restrictives et forces motrices (phénomènes de résistance au changement selon le modèle de Levine); approches du changement (empirico-rationnelles, normatives-rééducatives, coercitives, consensuelles, conflictuelles, contre-culturelles); définition des objectifs au cours d'une intervention; stratégies en fonction du pouvoir dont dispose l'agent de changement.

On se saurait trop insister sur l'importance qu'il faut attacher au processus de changement lorsqu'on réalise rapidement que le succès ou l'échec d'une intervention dans les systèmes sociaux en découle justement.

Il se suffit pas de croire que, par un décret ou par des modifications de politiques, de directives ou de procédures, le changement va se produire automatiquement; il faut laisser le temps aux gens impliqués de réfléchir, de cheminer à leur rythme, vu la situation nouvelle que l'on veut créer: c'est pourquoi le choix d'une démarche, d'une approche ou d'une stratégie devient importante au cours d'une intervention dans les organisations de travail.

Les auteurs n'optent pas pour une approche de changement planifiée plutôt qu'une autre. Ils prennent donc soin de faire les quelques distinctions qui s'imposent entre le changement planifié et le courant du «développement des organisations» d'origine nordaméricaine. Ce dernier s'inspire de valeurs d'autonomie de la personne humaine, de confiance mutuelle, de participation, de développement personnel. La relation d'aide qui se crée et se développe entre l'agent du changement et le système destinataire dans un processus de développement organisationnel diffère généralement du type de relations qui 